\title{
Biocidal Effects of Alligator Pepper (Afromomum melegueta) Extract on Larval Anurans in Nigeria
}

\author{
Jacob E. Ighere
}

School of Applied Science and Technology, Delta State Polytechnic, Otefe-Oghara, Nigeria (jeighere@yahoo.com)

$\mathrm{M}$ any species of amphibians are threatened by human activities and diseases and are the objects of intense conservation efforts throughout the world (e.g., Amphibiaweb 2009). The Alligator Pepper (Aframomum melegueta), which is a common spice plant in coastal regions of western Africa, has potential as a botanical pesticide that might replace chemical treatments (Adeyemo et al. 2014). In case it was employed to control pests in Nigeria, I tested the effects of a liquid extract from Alligator Pepper seeds on larval Common African Toads (Sclerophrys regularis) and African Groovecrowned Frogs (Hoplobatrachus occipitalis) (Fig. 1).

I collected fertilized amphibian eggs in a natural pond (Fig. 2) near Delta State Polytechnic, Otefe-Oghara, Nigeria. Those that were laid in strands and those in clusters were placed into separate containers of pond water and assigned to the Common African Toad and African Groove-crowned Frog, respectively. The containers were transferred to the lab and monitored until the eggs hatched. Seeds were removed from five dried Alligator Peppers, ground to powder, dissolved in $500 \mathrm{ml}$ of deionized water, left standing for a period of $24 \mathrm{~h}$, and filtered to obtain a clear extract.

As many as 100 four-day-old amphibian larvae were isolated in individually marked $250-\mathrm{ml}$ beakers. To compare the effects of the Alligator Pepper extract on other aquatic species, I also placed a number of mosquito larvae (Anopheles gambiae) into a $250-\mathrm{ml}$ beaker and three individuals each of adult Common African Toads, adult African Groove-crowned Frogs, Redbelly Tilapia (Tilapia zillii), and air-breathing catfish (Clarias sp.) into separate containers with $1,000 \mathrm{ml}$ of pondwater.

The Alligator Pepper extract was added to the containers at concentrations of 10,20,30, 40, and $50 \mathrm{ppm}$. The larval amphibians were monitored for $60 \mathrm{sec}$ and the other species for $24 \mathrm{~h}$.
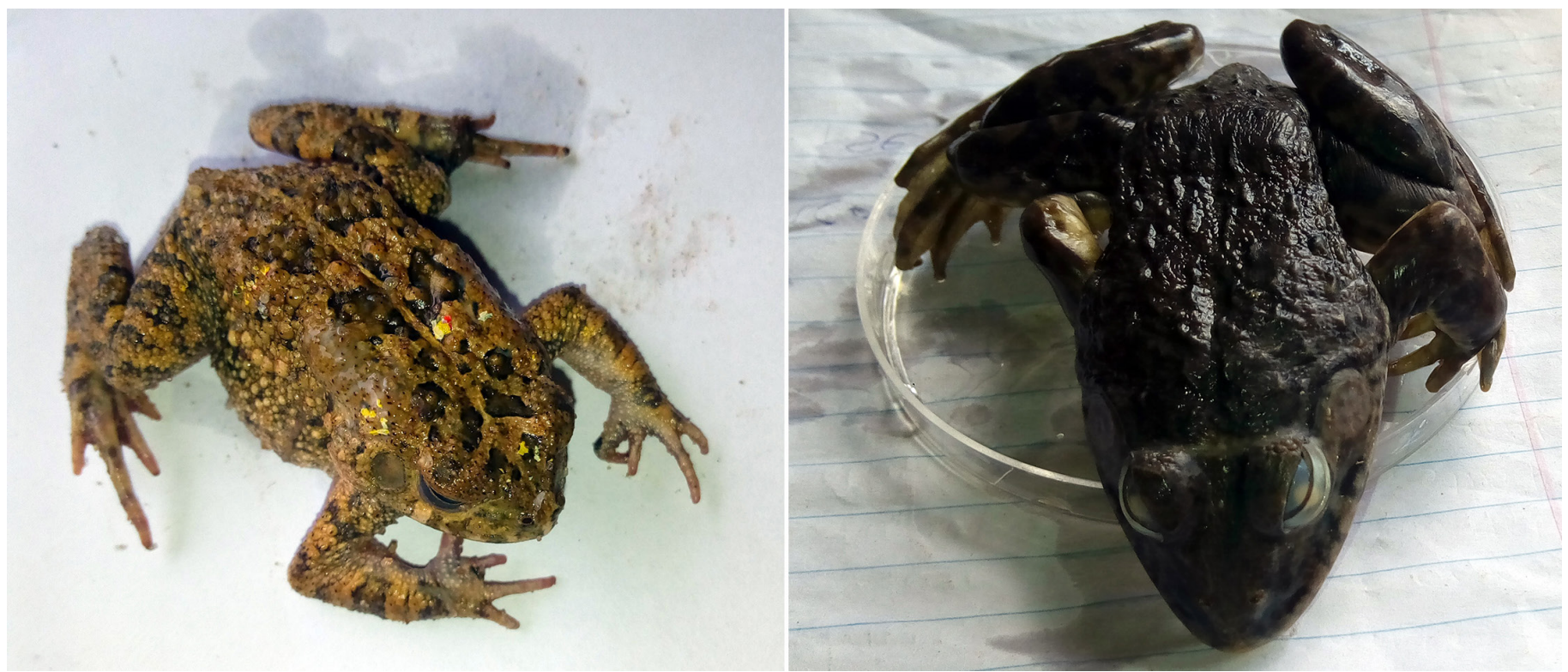

Fig. 1. Adult Common African Toad (Sclerophrys regularis) (left) and African Groove-crowned Frog (Hoplobatrachus occipitalis) (right) from Otefe-Oghara, Nigeria. 


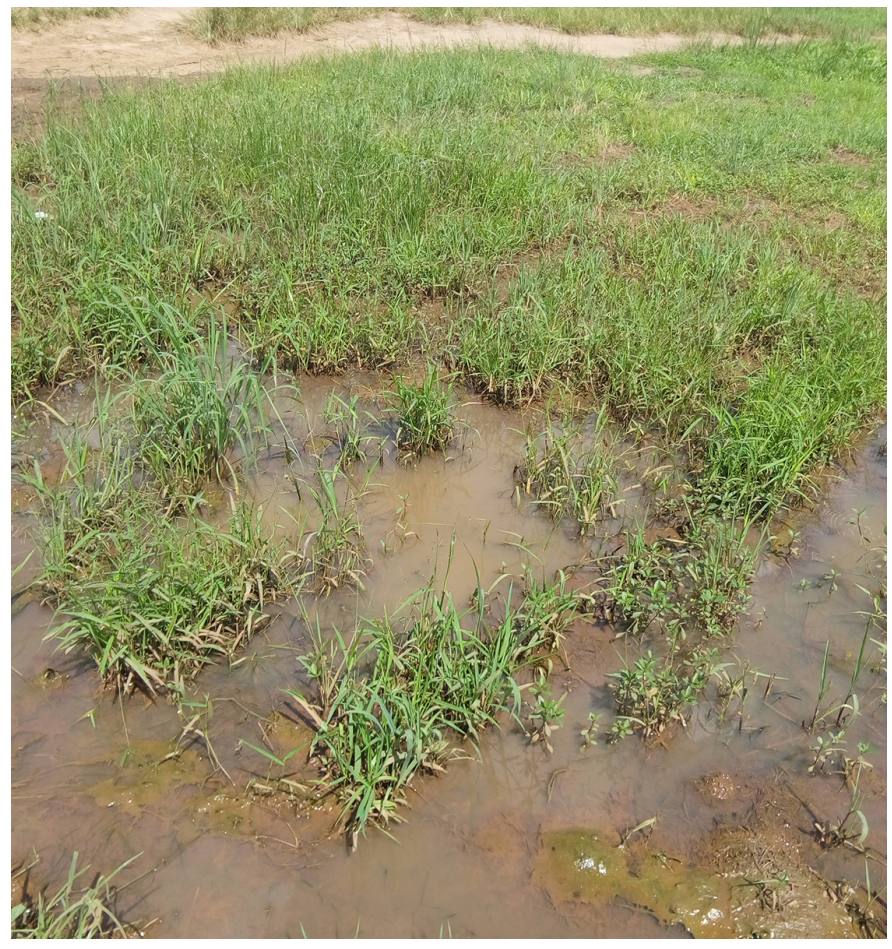

Fig. 2. The natural pond near Delta State Polytechnic, Otefe-Oghara, Nigeria, from which larval Common African Toads (Sclerophrys regularis) and African Groove-crowned Frogs (Hoplobatrachus occipitalis) were collected.

Biocidal effects of the Alligator Pepper extract on the amphibian larvae were substantial (Table 1), with 100\% mortality in both species within $60 \mathrm{sec}$ of exposure at concentrations of 40 and $50 \mathrm{ppm}$. The calculated $\mathrm{LD}_{50}$ was $2.5 \mathrm{ppm}$ for Sclerophrys regularis and $2.2 \mathrm{ppm}$ for Hoplobatrachus occipitalis. However, neither the mosquito larvae, adult anurans, nor the fish were affected even after four days of exposure to the extract.

Due to the lack of any effect on mosquito larvae, Alligator Pepper extract is unlikely to serve as an effective botanical pesticide. Nevertheless, its potential for use on other pests (e.g., Adeyemo et al. 2014) and its abundance and ready availability in Nigeria suggest that it might be employed in some situations. This study, however, clearly indicates that any applica-
Table 1. Biocidal effects of various concentrations of an Alligator Pepper extract on larval Common African Toads (Sclerophrys regularis) and African Groove-crowned Frogs (Hoplobatrachus occipitalis). Duration of exposure $=60 \mathrm{sec}$.

\begin{tabular}{ccc}
$\begin{array}{c}\text { Concentration } \\
(\mathbf{p p m})\end{array}$ & $\begin{array}{c}\text { Mortality } \\
\text { Sclerophrys regularis }\end{array}$ & $\begin{array}{c}\text { Mortality } \\
\text { Hoplobatrachus occipitalis }\end{array}$ \\
\hline 10 & 40 & 45 \\
\hline 20 & 60 & 68 \\
\hline 30 & 75 & 80 \\
\hline 40 & 100 & 100 \\
\hline 50 & 100 & 100 \\
\hline
\end{tabular}

tions of the extract would have a severely damaging impact on larval anurans despite leaving adult amphibians and fishes unaffected. Because of the obvious value of amphibians (West 2018 and references therein), I suggest that the biocidal effects on anuran larvae outweigh any benefits of employing Alligator Pepper extract as a botanical pesticide.

\section{Acknowledgements}

I thank the administration of Delta State Polytechnic, OtefeOghara for providing facilities and support. Final-year undergraduate students in the department of Biological Sciences assisted in collecting and monitoring the aquatic animals used in the study. Dr. Mark-Oliver Rödel and Gregory Jongsma confirmed the identity of the anurans from photographs.

\section{Literature Cited}

Adeyemo, A.C., M.O. Ashamo, and O.O. Odeyemi. 2014. Aframomum melegueta: A potential botanical pesticide against Sitotroga cerealella infestation on two paddy varieties. Archives of Phytopathology and Plant Protection 47: 1841-1851.

AmphibiaWeb. 2017. Worldwide Amphibian Declines: What is the scope of the problem, what are the causes, and what can be done? <https://amphibiaweb. org/declines/declines.html>.

West, J. 2018. Importance of Amphibians: A Synthesis of Their Environmental Functions, Benefits to Humans, and Need for Conservation. Unpublished Honors Thesis, Bridgewater State University, Bridgewater, Massachusetts, USA. <http://vc.bridgew.edu/honors_proj/261>. 